\title{
Pembuatan Biodiesel dengan Cara Adsorpsi dan Transesterifikasi Dari Minyak Goreng Bekas
}

\author{
Lisa Adhani ${ }^{1}$, Isalmi Aziz $^{2}$, Siti Nurbayti ${ }^{2}$, Cristie Odi Oktaviana ${ }^{2}$ \\ ${ }^{1}$ Program Studi Teknik Kimia Fakultas Teknik Universitas Bayangkara \\ Jl.Darmawangsa I/1 Kebayoran Baru Jakarta Selatan12140 \\ ${ }^{2}$ Program Studi Kimia FST UIN Syarif Hidayatullah Jakarta \\ Jl. Ir. H. Juanda No.95 Ciputat Jakarta 15412 \\ Email: lisaadhani@gmail.com
}

Received: April 2016; Revised: Mei 2016; Accepted: Mei 2016; Available Online: Mei 2016

\begin{abstract}
Abstrak
Minyak goreng bekas dapat digunakan sebagai bahan baku pembuatan biodiesel tetapi kadar asam lemak bebasnya (Free Fatty Acid, FFA) cukup tinggi. Untuk itu perlu dilakukan pretreatment berupa proses adsorpsi untuk menurunkan kadar FFA. Penelitian ini bertujuan untuk menentukan kondisi optimum proses adsorpsi dan menentukan kualitas biodiesel yang dihasilkan dari proses adsorpsi dan transesterifikasi. Zeolit alam yang digunakan sebagai adsorben terlebih dahulu diaktivasi menggunakan ammonium klorida, dikalsinasi dan dipanaskan sehingga didapatkan H-zeolit. Selanjutnya dilakukan optimasi proses adsorpsi meliputi waktu, konsentrasi adsorben, suhu dan ukuran partikel. Minyak yang sudah di adsorpsi direaksikan dengan metanol dan katalis KOH sehingga didapatkan biodiesel. Kondisi optimum adsorpsi didapatkan pada waktu 90 menit, konsentrasi H-zeolit $12 \%$, suhu $90^{\circ} \mathrm{C}$, dan ukuran partikel $0,2 \mathrm{~mm}$ yang mampu menurunkan kadar FFA dari 3,2\% menjadi 1,1\%. Kualitas Biodiesel yang dihasilkan memenuhi persyaratan SNI 04-7182-2006 dengan nilai kadar air 0,02\%, massa jenis $857,60 \mathrm{~kg} / \mathrm{m}^{3}$, bilangan asam $0,29 \mathrm{mg}-\mathrm{KOH} / \mathrm{g}$, bilangan iod 15,71 , bilangan penyabunan 168,02 dan indeks setana 75,62. Senyawa yang terkandung dalam biodiesel ini adalah metil 9oktadekanoat $(49,45 \%)$, metil heksadekanoat $(20,79 \%)$, dan metil 9,12-oktaekanoat $(18,87 \%)$.
\end{abstract}

Kata kunci: Biodiesel, minyak goreng bekas, adsorpsi, transesterifikasi, H-zeolit

\begin{abstract}
Used cooking oil can be used as raw material for biodiesel, but the levels of free fatty acids (Free Fatty Acid, FFA) is quite high. It is necessary for pretreatment in the form of the adsorption process to reduce levels of FFA. This study aims to determine the optimal conditions of adsorption process and determine the quality of biodiesel produced from adsorption processes and transesterification. Natural zeolites are used as adsorbents activated beforehand using ammonium chloride, calcined and heated to obtain H-zeolite. Furthermore, the adsorption process optimization includes the time, the adsorbent concentration, temperature and particle size. The oil that is already in the adsorption catalyst is reacted with methanol and $\mathrm{KOH}$ to obtain biodiesel. The optimum adsorption conditions obtained at the time of 90 minutes, the concentration of H-zeolite $12 \%$, temperature $90^{\circ}$ $\mathrm{C}$, and a particle size of $0.2 \mathrm{~mm}$ that can lower FFA levels from $3.2 \%$ to $1.1 \%$. Biodiesel produced meets the quality requirements of SNI 04-7182-2006 with a water content of $0.02 \%$, a density of $857.60 \mathrm{~kg} / \mathrm{m} 3$, the acid value of $0.29 \mathrm{mg}-\mathrm{KOH} / \mathrm{g}$, iodine number 15.71, saponification 168,02 and cetane index of 75.62. Compounds contained in biodiesel are methyl 9-octadecanoic (49.45\%), methyl heksadekanoat (20.79\%), and methyl 9,12oktaekanoat $9.12(18.87 \%)$.
\end{abstract}

Keywords: Biodiesel, used cooking oil, adsorption, transesterification, $H$-zeolit

DOI: http://dx.doi.org/10.15408/jkv.v2i1.3107 


\section{PENDAHULUAN}

Biodiesel adalah bahan bakar alternatif untuk mesin diesel yang dihasilkan dari reaksi transesterifikasi antara minyak nabati atau lemak hewani yang mengandung trigliserida dengan alkohol seperti metanol dan etanol. Reaksi transesterifikasi ini memerlukan katalis basa kuat seperti natrium hidroksida atau kalium hidroksida sehingga menghasilkan senyawa kimia baru yang disebut dengan metil ester (Gerpen, 2005).

Salah satu contoh minyak nabati yang dapat dimanfaatkan untuk pembuatan biodiesel antara lain minyak goreng bekas. Bahan ini dinilai lebih ekonomis dan berdayaguna. Namun kekurangannya adalah kandungan asam lemak bebas (Free Fatty Acid, FFA) yang tinggi dan adanya senyawa pengotor lainnya. Kadar FFA yang tinggi dapat menghambat reaksi pembentukan biodiesel, karena KOh yang digunakan sebagai katalis akan bereaksi dengan FFA membentuk sabun. Selain itu sabun yang dihasilkan akan mempersulit separasi pemurnian biodiesel. Oleh karena itu perlu diadakan pretreatment terhadap minyak goreng bekas sebelum diproses menjadi biodiesel agar kandungan FFAnya dapat diturunkan.

Aziz et al., (2011) melakukan proses esterifikasi untuk menurunkan kandungan FFA dalam minyak goreng bekas. Produk esterifikasi selanjutnya dilakukan transesterifikasi. Permasalahan yang timbul adalah katalis asam sulfat yang digunakan pada proses esterifikasi sulit dipisahkan dari produk sehingga dapat mengganggu proses transesterifikasi. Maka pada penelitian ini digunakan proses adsorpsi menggunakan zeolit alam yang berasal dari Lampung untuk menurunkan kadar asam lemak bebas (FFA) dan dilanjutkan dengan proses transesterifikasi. Pemilihan zeolit zeolit alam dari Lampung ini didasarkan pada kualitasnya yang baik. Selain itu karena ketersediannya yang cukup melimpah, harga murah dan aman. Sebelum digunakan zeolit alam terlebih dahulu diaktivasi untuk menghilangkan senyawa pengotor yang terdapat dalam zeolit tersebut.

Zeolit alam yang telah diaktivasi mempunyai kemampuan sebagai adsorben. Proses aktivasi menyebabkan terjadinya perubahan perbandingan $\mathrm{Si} / \mathrm{Al}$, luas permukaan meningkat, dan terjadi peningkatan porositas zeolit (Setiadji, 1996). Hal ini dapat meningkatkan kinerja zeolit, yaitu meningkatkan kemampuan adsoprsi zeolit sehingga lebih efisien dalam menurunkan jumlah asam lemak bebas,. Perlakuan adsorpsi ini diharapkan dapat memberikan pengaruh terhadap kualitas biodiesel yang dihasilkan.

Penelitian ini bertujuan untuk menentukan kondisi optimum proses adsorpsi (waktu, konsentrasi adsorben, dan suhu) dan menentukan kualitas biodiesel yang dihasilkan dari proses adsorpsi dan transesterifkasi.

\section{METODE PENELITIAN}

\section{Alat dan Bahan}

Alat yang digunakan dalam penelitian ini adalah GCMS QP-2010 Shimadzu Japan, piknometer, hotplate, neraca analitik, oven, termometer, magnetik stirer, satu set alat refluks dan reaktor yg dilengkapi dengan kondensor. Bahan yang digunakan dalam penelitian ini antara lain minyak goreng bekas yang berasal dari salah satu tempat makan di wilayah kampus UIN Syarif Hidayatullah Jakarta, $\mathrm{H}_{2} \mathrm{SO}_{4}$ pekat, metanol, akuades, padatan $\mathrm{KOH}$, etanol 96\%, $\mathrm{HCl}, \mathrm{NaOH}$, $\mathrm{NH}_{4} \mathrm{Cl}, \mathrm{AgNO}_{3}$, Phenolphthalein (PP), KI, $\mathrm{Na}_{2} \mathrm{~S}_{2} \mathrm{O}_{3}$, pereaksi Wijs, larutan kanji, kloroform, dan zeolit alam. Zeolit ini diperoleh dari CV.Winatama Mineral Perdana di Desa Kalianda Lampung. Zeolit ini berwarna putih dengan jenis klinoptilolit.

\section{Aktivasi Zeolit Alam Lampung (Las, 1989)}

Zeolit alam direndam dalam akuades sambil diaduk selama 3 hari (tiap hari selama 8 jam) pada temperatur kamar. Kemudian disaring, endapan yang bersih dikeringkan dalam oven pada temperatur $120{ }^{\circ} \mathrm{C}$ selama 2 jam. Selanjutnya zeolit direndam ke dalam larutan $\mathrm{NH}_{4} \mathrm{Cl} 1 \mathrm{M}$ selama 24 jam pada temperatur kamar. Setelah selesai, zeolit disaring, dicuci dengan akuades dan diuji kandungan ion kloridanya $\left(\mathrm{Cl}^{-}\right)$menggunakan larutan perak nitrat $\left(\mathrm{AgNO}_{3}\right)$ hingga tidak terdapat endapan putih $\mathrm{AgCl}$. Kemudian zeolit dikeringkan dalam oven pada temperatur 120 ${ }^{0} \mathrm{C}$. Setelah dingin, zeolit diletakkan dalam cawan porselin dan dikalsinasi semalaman, pada temperatur $450{ }^{0} \mathrm{C}$ dalam furnace. Selanjutnya didinginkan dan diperoleh zeolit aktif (H-zeolit). 


\section{Adsorpsi dengan H-zeolit}

Minyak goreng bekas sebanyak 350 gram, dimasukkan ke dalam gelas beker 500 $\mathrm{ml}$, kemudian ditambah H-zeolit sebanyak $12 \%$ dari berat minyak goreng bekas. Campuran diaduk dengan menggunakan pengaduk berdasarkan variasi waktu adsorpsi oleh zeolit $(30,45,60,75$, dan 90 menit) dan dipanaskan pada suhu $70{ }^{\circ} \mathrm{C}$. Selanjutnya dianalisa kadar FFA.

Setelah didapatkan waktu adsorpsi optimum, selanjutnya secara berturut-turut dilakukan variasi konsentrasi adsorben $(\mathrm{H}-$ zeolit) $(6 \%, 9 \%, 12 \%, 15 \%$, dan $18 \%$ dari berat minyak goreng bekas); ukuran partikel H-zeolit (2 mm, $0.2 \mathrm{~mm}$, dan $0.63 \mathrm{~mm})$ dan suhu adsorpsi $\left(30^{\circ} \mathrm{C}, 50{ }^{\circ} \mathrm{C}, 70{ }^{\circ} \mathrm{C}, 90{ }^{\circ} \mathrm{C}, 110\right.$ $\left.{ }^{\circ} \mathrm{C}\right)$.

\section{Analisis kandungan asam lemak bebas (Mechlenbacher, 1960)}

Sampel minyak ditimbang sebanyak $1.6 \mathrm{~g}$ dalam erlenmeyer dan ditambahkan dengan $50 \mathrm{ml}$ etanol $96 \%$ kemudian dipanaskan dalam waterbath sampai larutan homogen. Setelah dingin dititrasi dengan $\mathrm{KOH}$ $0.1 \mathrm{~N}$ dan ditambahkan indikator phenoftalein 1\%. Larutan dititrasi hingga berwarna merah jambu tercapai dan tidak hilang selama 30 detik.

\section{Proses Transesterifikasi (Aziz, 2007)}

Padatan KOH sebanyak 0.46 gram dilarutkan dalam $12.5 \mathrm{~mL}$ metanol kemudian dicampurkan dalam $50 \mathrm{~mL}$ minyak goreng bekas hasil pretreatment (setelah dilakukan adsorpsi) yang telah dipanaskan hingga suhu $60{ }^{\circ} \mathrm{C}$. Laju pengadukan diatur sebesar 1000 rpm. Reaksi dibiarkan selama 60 menit dan suhunya dijaga konstan. Hasil reaksi dimasukkan ke dalam corong pemisah, kemudian dibiarkan selama 12 jam sampai terjadi pemisahan yang sempurna. Lapisan atas menunjukkan biodiesel dan lapisan bawah menunjukkan crude gliserol. Lapisan biodiesel dipisahkan dan dipanaskan pada suhu $70{ }^{\circ} \mathrm{C}$ agar metanol menguap.

\section{Karakterisasi Biodiesel}

Biodiesel yang dihasilkan di uji sifat fisik dan kimianya seperti angka asam, massa jenis, bilangan iod, bilangan penyabunan, kadar abu tersulfatkan, kadar airGdan senyawa penyusun biodiesel menggunakan GC-MS.

\section{Uji Angka Asam}

Sampel biodiesel sebanyak $20 \mathrm{~g}$ dimasukkan ke dalam Erlenmeyer dan ditambahkan $50 \mathrm{ml}$ alkohol 95\%. Kemudian dipanaskan dalam penangas air hingga mendidih dalam penangas air sambil diaduk sampai terbentuk larutan homogen. Setelah dingin,dititrasi dengan $\mathrm{KOH} \quad 0.1 \quad \mathrm{~N}$ menggunakan indikator PP sampai terbentuk warna merah jambu yang tidak hilang selama 30 detik. Bilangan asam dihitung dengan perhitungan berikut :

Bilangan asam $=\frac{\mathrm{ml} \mathrm{KOH} \times \mathrm{xN} \mathrm{KOH} \times 56.1}{\text { Berat Sample }}$

\section{Massa Jenis Pada Suhu $40{ }^{\circ} \mathrm{C}$ (ASTM D} 1298)

Pada suhu $40{ }^{\circ} \mathrm{C}$ yakni cuci dan bersihkan piknometer dengan aquades dilanjutkan dengan etanol kemudian dikeringkan dalam oven. Timbang bobot piknometer kosong (mk), Isi piknometer dengan aquadest pada suhu $40{ }^{\circ} \mathrm{C}$ sampai penuh (tanda tera). Piknometer dimasukkan dalam penangas air pada suhu $40{ }^{\circ} \mathrm{C}$ selama 30 menit.suhu penangas air dipastikan $40{ }^{\circ} \mathrm{C}$ lalu ditimbang piknometer berisi aquadest (ma). Piknometer dikosongkan dan dicuci dengan alkohol lalu dikeringkan. Diisi piknometer dengan biodiesel suhu $40{ }^{\circ} \mathrm{C}$ sampai tanda tera. Piknometer dimasukkan dalam penangas air suhu $40{ }^{\circ} \mathrm{C}$ selama 30 menit, kemudian diangkat dan dibersihkan permukaannya dengan kertas tisu, Timbang neraca analitik $(\mathrm{mb})$, massa jenis ditentukkan dengan rumus berikut:

$\rho b=\left(\frac{(m b-m k)}{(m a-m k)} \times \rho a\right)$

$\rho \mathrm{b}=$ massa jenis biodiesel

$\rho \mathrm{a}=$ massa jenis aquadest pada suhu $40^{\circ} \mathrm{C}=993 \mathrm{~kg} / \mathrm{m}^{3}$

\section{Bilangan Iod (AOCS Cd 1-25)}

Sampel biodiesel ditimbang 0.4 gram di dalam Erlenmeyer bertutup, kemudian dipanaskan. Ditambahkan $15 \mathrm{ml}$ kloroform untuk melarutkan sampel minyak. Ditambahkan $25 \mathrm{ml}$ pereaksi Wijs, ditempatkan di ruang gelap selama 30 menit sambil sekali-sekali dikocok. Ditambahkan 20 $\mathrm{ml}$ larutan KI 15\%, dikocok merata. Labu Erlenmeyer dan tutupnya dicuci dengan 150 $\mathrm{ml}$ aquadest yang baru dan dingin, dan cucian dimasukkan ke dalam larutan. Dititrasi dengan 
$\mathrm{Na}_{2} \mathrm{~S}_{2} \mathrm{O}_{3} \quad 0.1 \mathrm{~N}$ dengan pengocokan yang konstan hingga warna kuning hilang, lalu ditambahkan 1-2 ml indikator kanji atau pati 1\% sebagai indikator. Titrasi dilanjutkan hingga warna biru hilang. Penentapan blanko dibuat dalam waktu dan kondisi yang sama. Pekerjaan dilakukan dua kali (duplo). Blanko dibuat seperti pada penetapan sample, dimana minyak diganti dengan kloroform. Bilangan iod dihitung dengan menggunakan perhitungan berikut :

Bil. Iod $=\left(\frac{\text { (titerblonibo-titersompeiDmirNWo25203x } 12.69}{\text { Berat sample }(\text { gram })}\right)(3)$

12.69 adalah bobot setara dari bilangan iod.

126.9adalah berat atom bilangan iod.

\section{Kadar Air (SNI 01-2901-2006)}

Sampel sebanyak 3-5 gram ditimbang dan dimasukkan dalam cawan yang telah dikeringkan dan diketahui bobotnya. Kemudian sampel dan cawan dikeringkan dalam oven bersuhu $105{ }^{\circ} \mathrm{C}$ selama 3 jam. Kemudian cawan didinginkan dan ditimbang kemudian dikeringkan kembali sampai diperoleh bobot yang konstan. Kadar air sampel dapat dihitung dengan menggunakan rumus sebagai berikut.

Kadar air $=\frac{a-(b-c)}{a} \times 100 \%$

$\mathrm{a}=$ bobot sampel awal

$\mathrm{b}=$ bobot sampel akhir+ cawan

$\mathrm{c}=$ bobot cawan

\section{Bilangan Penyabunan (FBI-A03-03)}

Sebanyak 5 gram sampel dimasukkan ke dalam Erlenmeyer $250 \mathrm{ml}$ dan ditambahkan $50 \mathrm{ml}$ larutan $\mathrm{KOH}$ alkoholik. Labu Erlenmeyer disambungkan dengan kondensor berpendingin udara dan larutan di dalam labu dididihkan selama 30 menit hingga sampel tersabun sempurna. Larutan yang diperoleh pada akhir penyabunan harus jernih dan homogen. Jika tidak maka waktu penyabunan diperpanjang. Larutan dibiarkan cukup dingin, kemudian dinding dalam kondensor dibilas dengan aquadest. Labu dilepaskan dari kondensor lalu larutan di dalam labu ditambah $1 \mathrm{ml}$ larutan indikator fenolftalein ke dalam labu dan dititrasi dengan $\mathrm{HCl} 0.5 \mathrm{~N}$ sampai warna merah jambu hilang minimal selama 15 detik. Prosedur yang sama juga dilakukan untuk blanko.

$$
B s=\left(\frac{56,1 x(V b-V c) x N}{m}\right)
$$

Bs : bilangan sabun (mg KOH/g biodiesel)

$\mathrm{Vb}$ : volume $\mathrm{HCl}$ untuk titrasi blanko $(\mathrm{ml})$

$\mathrm{Vc}$ : volume $\mathrm{HCl}$ untuk titrasi sampel $(\mathrm{ml})$

$\mathrm{N}$ : normalitas larutan $\mathrm{HCl} 0.5 \mathrm{~N}$

$\mathrm{m}$ : berat sampel biodiesel $(\mathrm{g})$

\section{Analisa Komposisi Senyawa dalam \\ Biodiesel dengan GCMS}

Sampel sebanyak $1 \mu \mathrm{L}$ diinjeksikan ke dalam kolom GC dengan menggunakan kolom autosampler. Pemisahan dilakukan dalam kolom RTx 1-Ms Restech, $30 \mathrm{~m}$ x $0.25 \mathrm{~mm}$ ID, $0.25 \mu \mathrm{m}$, dengan fase diam Poly di metyl xiloxane, suhu injektor $280{ }^{\circ} \mathrm{C}$, suhu kolom 70 ${ }^{0} \mathrm{C}$ dinaikkan sampai $300{ }^{\circ} \mathrm{C}$ dengan kenaikan $10{ }^{0} \mathrm{C} / \mathrm{menit}$, laju alir $1.15 \mathrm{~mL} / \mathrm{menit}$. Hasil analisi berupa spektrum massa dibandingkan dengan library software GCMS postrum analysis.

\section{HASIL DAN PEMBAHASAN}

\section{Pengaruh Waktu Adsorpsi terhadap Kadar FFA}

Variabel pertama yang dilakukan pada penelitian ini adalah pengaruh waktu reaksi. Variasi waktu yang digunakan adalah 30, 45, 60, 75, 90, 105 menit dengan parameter kondisi reaksi lainnya dibuat konstan yaitu suhu $70{ }^{\circ} \mathrm{C}$ dan ukuran partikel zeolit $0.2 \mathrm{~mm}$. Waktu optimum reaksi merupakan waktu efektif dan efisien terhadap penurunan kadar FFA yang terkandung pada minyak goreng bekas. Pengaruh waktu reaksi terhadap kadar FFA dapat dilihat pada Gambar 1.

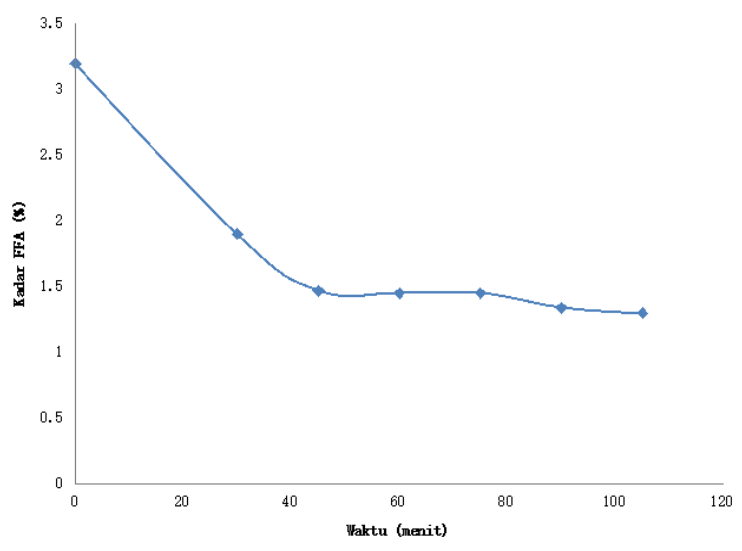

Gambar 1. Pengaruh waktu terhadap kadar FFA $(\%)$ 
Gambar 1 memperlihatkan bahwa proses adsorpsi yang dilakukan mampu menurunkan kadar FFA dalam minyak goreng bekas. Kadar FFA mengalami penurunan seiring dengan bertambahnya waktu. Kadar FFA dalam minyak goreng bekas sebelum proses adsorpsi sebesar $3.2 \%$. Pada 30 menit pertama kadar FFA yang dihasilkan yaitu 1.9\%. Pada waktu 45, 60, dan 75 menit masing-masing menghasilkan kadar FFA sebesar $1.5 \%, 1.4 \%$, dan $1.45 \%$. Pada waktu 90 menit kadar FFA sebesar $1.3 \%$. Tetapi, ketika mencapai menit ke 105 kadar FFA konstan yaitu $1.3 \%$. Hal ini menunjukkan bahwa adsorpsi minyak goreng bekas oleh zeolit reaksi mendekati titik kesetimbangan. Pada waktu adsorpsi 90 dan 105 menit terjadi kesetimbangan adsorpsi, dimana jumlah zat teradsorpsi hampir sebanding dengan zat yang terdesorpsi (Yusnimar, 2008).

Hasil penelitian menunjukkan semakin lama waktu adsorpsi maka kadar FFA semakin turun. Menurut Suarya (2008), adanya peningkatan penyerapan adsorbat oleh adsorben menunjukkan belum jenuhnya situs aktif adsorben oleh molekul adsorbat, namun pada kondisi konsentrasi adsorbat yang teradsorpsi telah konstan diakibatkan oleh jenuhnya situs aktif dari adsorben oleh molekul adsorbat. Hal ini juga menunjukkan bahwa adanya batas adsorben dalam mengadsorpsi adsorbat yang dalam hal ini adalah FFA yang terkandung dalam minyak goreng bekas.

Kemampuan senyawa silikat yang berada pada zeolit untuk menurunkan kadar FFA dapat disebabkan karena adanya gugus silanol $(\mathrm{Si}-\mathrm{OH})$ pada permukaan zeolit. Yang (2003) menyebutkan bahwa gugus silanol inilah yang berperan dalam adsorpsi air dan senyawa organik. Gugus oksigen dengan karbonil pada FFA yang bereaksi dengan hidrogen- silanol, sehingga molekul FFA teradsorpsi pada permukaan dengan membentuk ikatan hidrogen. Gambar 2 menunjukkan ikatan yang terjadi antara gugus silanol dengan asam lemak bebas.

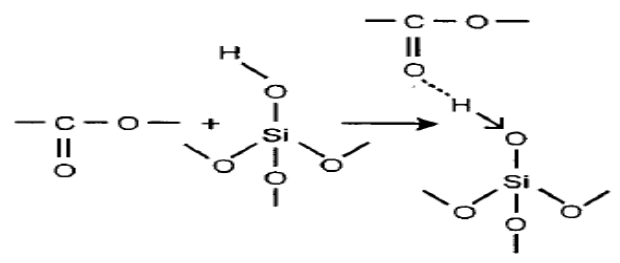

Gambar 2. Interaksi zeolit dengan asam lemak bebas

\section{Pengaruh Konsentrasi Adsorben terhadap Kadar FFA}

Setelah diperoleh waktu optimum 90 menit, parameter selanjutnya yang divariasikan adalah konsentrasi adsorben. Berdasarkan data yang dihasilkan untuk kadar FFA dapat dilihat pada Gambar 3.

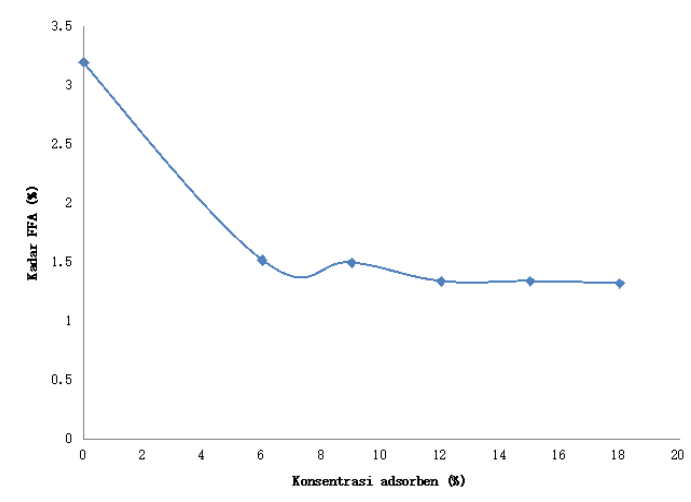
Gambar 3. Pengaruh konsentrasi adsorben
terhadap kadar FFA

Gambar 3 memperlihatkan bahwa pada konsentrasi $6 \%$ memiliki kadar FFA $1.5 \%$. Konsentrasi $9 \%$ menghasilkan kadar FFA $1.5 \%$. Peningkatan adsorpsi terjadi pada konsentrasi $12 \%$ dengan kadar FFA $1.3 \%$. Penambahan konsentrasi $15 \%$ dan $18 \%$ memiliki kadar FFA yang konstan yaitu $1.3 \%$. Hal ini disebabkan pada konsentrasi $15 \%$ dan $18 \%$ telah mengalami kesetimbangan dimana adsorben (zeolit) sudah mengalami kejenuhan, sehingga tidak bisa menyerap adsorbat lagi.

Semakin besar konsentrasi zeolit yang ditambahkan maka kadar FFA semakin berkurang. Hal ini disebabkan penambahan konsentrasi zeolit akan meningkatkan jumlah total luas permukaan dan jumlah pori yang digunakan untuk mengikat adsorbat dalam proses adsorbsi. Parameter konsentrasi zeolit yang digunakan juga berpengaruh terhadap luas bidang kontak antara adsorben dengan adsorbat.

Dari data di atas dapat disimpulkan bahwa konsentrasi zeolit $12 \%$ adalah konsentrasi paling optimum dengan kadar FFA sebesar $1.3 \%$. Hasil ini sama seperti penelitian yang dilakukan Suseno (2010) yang mendapatkan konsetrasi optimum sebesar $12 \%$. 


\section{Pengaruh Suhu Adsorpsi terhadap Kadar FFA}

Parameter yang ketiga yang diuji adalah pengaruh suhu. Waktu dan konsentrasi optimum digunakan sebagai parameter konstan pada optimasi suhu yaitu pada waktu 90 menit dan konsentrasi 12\%. Gambar 4 yang menunjukkan pengaruh suhu terhadap kadar FFA.

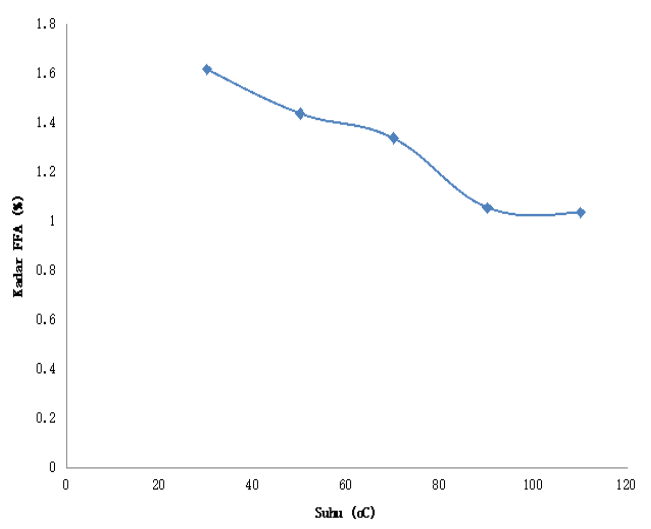

Gambar 4. Pengaruh suhu terhadap kadar FFA

Ditinjau dari grafik yang terdapat pada Gambar 4, diketahui bahwa seiring dengan kenaikan suhu adsorpsi, naik pula nilai penurunan FFA yang diperoleh. Pada suhu kamar $30{ }^{\circ} \mathrm{C}$ kadar FFA yang dimiliki $1.6 \%$. Hal ini menunjukkan bahwa proses adsorpsi minyak goreng bekas dengan menggunakan $\mathrm{H}$ zeolit dapat dilakukan pada suhu kamar tanpa memerlukan pemanasan. Ketika suhu dinaikkan menjadi $50{ }^{\circ} \mathrm{C}$, maka kadar FFA menjadi $1.4 \%$. Penurunan yang paling tajam terjadi pada suhu $70{ }^{\circ} \mathrm{C}$ menuju $90{ }^{\circ} \mathrm{C}$ yaitu dari kadar FFA $1.3 \%$ menjadi $1.1 \%$. Pada saat temperatur $110{ }^{\circ} \mathrm{C}$ tidak terjadi perubahan kadar FFA. Kenaikan suhu adsorpsi dapat meningkatkan energi kinetik molekul-molekul pengotor yang terdapat dalam minyak goreng bekas, sehingga molekul-molekul pengotor ini mampu berdifusi lebih cepat ke dalam poripori adsorben (Hidayat et al., 2010)

Berdasarkan hasil penelitian dapat ditentukan bahwa suhu terbaik untuk penurunan kadar FFA yang terdapat pada minyak goreng bekas dengan metode yaitu pada suhu $90{ }^{\circ} \mathrm{C}$. Penelitian yang dilakukan oleh Susantiani, E (2009) yang menyatakan bahwa pada adsorpsi fisik, adsorpsi semakin menurun dengan meningkatnya temperatur. Hal ini terjadi karena meningkatnya temperatur menyebabkan desorpsi semakin besar.
Desorpsi terjadi akibat permukaan adsorben yang telah jenuh. Pada keadaan jenuh, jumlah adsorbat yang teradsorpsi akan terlepas dari pori-pori adsorben sehingga laju adsorpsi menjadi berkurang. Berdasarkan hasil ini, diduga mekanisme adsorpsi didominasi oleh adsorpsi fisika.

\section{Pengaruh Ukuran Partikel Adsorben terhadap kadar FFA}

Variabel keempat yang duji adalah ukuran partikel H-zeolit. Variasi ukuran partikel yang digunakan adalah $2 \mathrm{~mm}, 0.63$ $\mathrm{mm}$, dan $0.2 \mathrm{~mm}$. Grafik hubungan antara suhu adsorpsi dengan kadar FFA dilihat secara jelas pada Gambar 5.

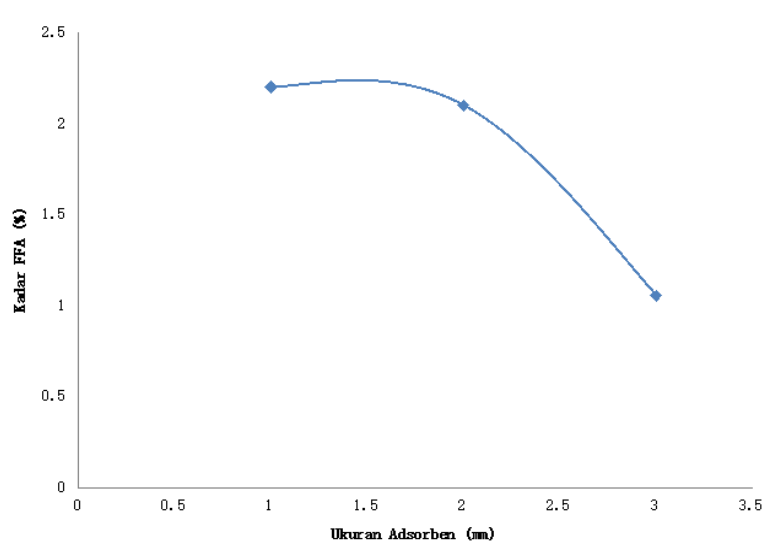

Gambar 5. Pengaruh ukuran partikel terhadap kadar FFA (\%)

Pada Gambar 5 dapat dilihat bahwa ukuran partikel zeolit memberikan pengaruh terhadap kadar FFA. Ukuran partikel $2 \mathrm{~mm}$ dan $0.63 \mathrm{~mm}$ memiliki kadar FFA yaitu $2.2 \%$ dan $2.1 \%$. Pada kedua ukuran tersebut tidak menghasilkan perubahan yang signifikan. Sedangkan pada ukuran partikel $0.2 \mathrm{~mm}$ menghasilkan kadar FFA terendah yaitu sebesar $1.1 \%$. Hal ini terjadi karena zeolit dengan ukuran partikel paling kecil memiliki luas permukaan yang lebih besar dibandingkan dengan zeolit lainnya. Semakin halus ukuran partikel zeolit maka daya serap akan semakin tinggi. Hal ini juga membuktikan bahwa ukuran partikel zeolit juga turut mempengaruhi daya adsorpsinya untuk menyerap sejumlah asam lemak bebas yang terikat pada minyak jelantah.

Hasil penelitian ini sama dengan yang dilakukan oleh Ramdja et al., (2010), yaitu pemurnian minyak jelantah menggunakan ampas tebu sebagai adsorben dimana ampas 
tebu dengan ukuran partikel paling kecil ini mampu menurunkan kadar asam lemak bebas yang terkecil hingga $0.0999 \%$ minyak jelantah. Selain kadar FFA yang berkurang, proses adsorpsi pada minyak goreng bekas juga mengakibatkan warna pada minyak goreng bekas semakin berkurang seiring dengan semakin kecilnya ukuran partikel pada adsorben. Menurut penelitian yang dilakukan Pakpahan et al., (2013) efisiensi adsorpsi merupakan fungsi luas permukaan adsorben, dimana semakin besar luas permukaan adsorben semakin besar pula kapasitas suatu adsorben dalam mengadsorpsi suatu adsorbat. Pengurangan warna yang paling efektif didapat pada saat proses adsorpsi menggunakan adsorben zeolit ukuran $0.2 \mathrm{~mm}$, hal ini sesuai dengan teori yang dinyatakan di atas. Gambar 6 menunjukkan hasil adsorpsi minyak goreng bekas dengan berbagai variasi ukuran partikel zeolite.

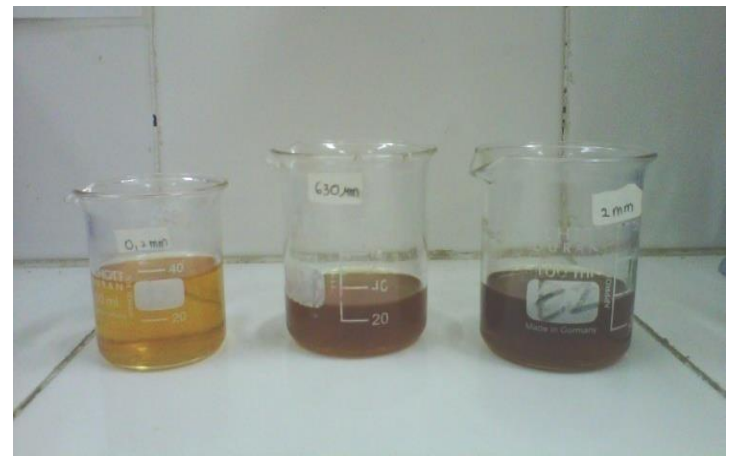

Gambar 6. Warna minyak goreng bekas dengan variasi ukuran zeolit

\section{Proses Transesterifikasi}

Pada dasarnya proses pembuatan biodiesel pada penelitian ini adalah mengubah minyak goreng bekas kedalam bentuk ester. Untuk memperoleh ester, minyak goreng bekas hasil adsorpsi pada kondisi optimum (waktu, konsentrasi, suhu, dan ukuran partikel) direaksikan dengan metanol (reaksi esterifikasi), dan untuk mempercepat jalannya reaksi maka ditambahkan katalisator yaitu $\mathrm{KOH}$. Rendemen biodiesel yang dihasilkan pada penelitian kali ini menghasilkan rendemen yang cukup tinggi yaitu sebsesar 93.64\%. Rendemen biodiesel dari bahan baku minyak goreng bekas dipengaruhi oleh kadar asam lemak bebas. Keberadaan asam lemak bebas akan mengakibatkan proses esterifikasi tidak berjalan sempurna karena aam lemak bebas akan bereaksi dengan metanol membentuk sabun (reaksi penyabunan). Sabun dapat membentuk emulsi dengan air dan gliserin sehingga pemisahannya menjadi lebih sulit. Selain itu, pembentukan sabun juga mengurangi perolehan biodiesel. Produk biodiesel yang dihasilkan dapat dilihat pada Gambar 7.

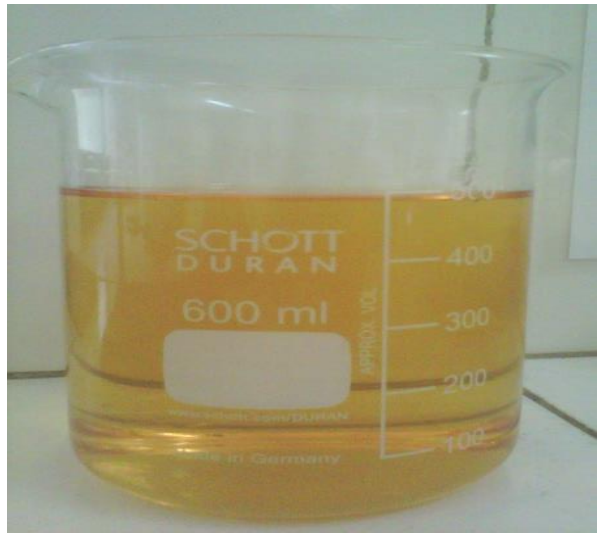

Gambar 7. Hasil Biodiesel

\section{Karakterisasi Biodiesel}

Analisis terhadap sifat fisik dan kimia produk biodiesel dilakukan untuk menentukan kualitas biodiesel yang kemudian diperbandingkan dengan biodiesel sesuai dengan standar SNI 04-7182-2006. Hasil penelitian pembuatan biodiesel yang didapatkan mempunyai sifat fisik dan kimia ditunjukkan pada Tabel 1.

Tabel 1. Hasil analisa sifat fisika dan kimia

\begin{tabular}{lll}
\hline Parameter & $\begin{array}{l}\text { Biodisel hasil } \\
\text { penelitian }\end{array}$ & SNI \\
\hline Kadar air & $0.02 \%$ & Maks. 0.05\% \\
Massa jenis $40{ }^{\circ} \mathrm{C}$ & $857.60 \mathrm{~kg} / \mathrm{m}^{3}$ & $850-890 \mathrm{~kg} / \mathrm{m}^{3}$ \\
Angka asam & $0.29 \mathrm{mg}-$ & Maks $0.8 \mathrm{mg}-\mathrm{KOH} / \mathrm{g}$ \\
& $\mathrm{KOH} / \mathrm{g}$ & \\
Bilangan & 168.02 & - \\
penyabunan & & \\
Bilangan iod & 15.71 & Maks. 115 \\
Angka setana & 75.62 & Min. 51 \\
\hline
\end{tabular}

biodiesel

\section{Kadar Air}

Berdasarkan Standar Nasional Indonesia kadar air yang terkandung dalam biodiesel maksimum $0.05 \%$. Kadar air merupakan salah satu tolak ukur mutu biodiesel. Berdasarkan data yang ada pada Tabel 4 kadar air yang terkandung di dalam biodiesel berbasis minyak goreng bekas yang telah diadsorpsi sebesar $0.02 \%$. Kadar air 
yang terkandung di dalam biodiesel lebih rendah bila dibandingkan dengan SNI sehingga biodiesel lebih aman. Kandungan air yang tinggi dalam biodiesel yang digunakan sebagai bahan bakar juga dapat menyebabkan turunnya panas pembakaran, berbusa, bersifat korosif jika bereaksi dengan sulfur karena akan membentuk asam, dan memberi ruang bagi mikroba untuk tumbuh sehingga akan menjadi pengotor bagi biodiesel.

\section{Massa Jenis}

Massa jenis biodiesel $\left(40{ }^{\circ} \mathrm{C}\right)$ yang dihasilkan sebesar $857.60 \mathrm{~kg} / \mathrm{m}^{3}$. Jika dibandingkan dengan standar SNI biodiesel, biodiesel ini masuk dalam range yang ditetapkan. Nilai massa jenis pada suatu biodiesel menunjukkan bahwa nilai kalor dan daya yang dihasilkan oleh mesin diesel per satuan volume bahan bakar. Menurut Peterson (2001), penggunaan katalis basa yang berlebih akan menyebabkan reaksi penyabunan. Hal ini memungkinkan adanya zat pengotor seperti sabun kalium dan gliserol hasil reksi penyabunan, asam-asam lemak yang tidak terkonversi menjadi metil ester (biodiesel), air, kalium hidroksida sisa, kalium metoksida ataupun sisa metanol yang menyebabkan massa jenis biodiesel menjadi lebih besar begitu sebaliknya jika penggunaan katalis basa kecil menyebabkan massa jenis biodiesel menjadi rendah. Massa jenis berkaitan dengan nilai kalor dan daya yang dihasilkan oleh pembakaran persatuan volume bahan bakar. Semakin besar nilai densitas menyatakan bahwa semakin banyak komponen yang terkandung di dalamnya. Banyaknya komponen yang terkandung dalam minyak memperpanjang proses atomisasi komponenkomponen penyusun minyak saat pembakaran, sehingga meningkatkan nilai kalor hasil pembakaran minyak.

\section{Angka Asam}

Berdasarkan hasil penelitian angka asam pada biodiesel adalah $0.29 \mathrm{mg}-\mathrm{KOH} / \mathrm{g}$. Nilai ini memenuhi standar biodiesel menurut SNI yaitu maksimal $0.8 \mathrm{mg} \mathrm{KOH} / \mathrm{g}$. Nilai angka asam yang kecil ini mengindikasikan bahawa asam lemak bebas sudah dapat dihilangkan melalui pretreatment (proses adsorpsi). Menurut Sangha et al., (2005) menyatakan bahwa bilangan asam yang terlalu tinggi tidak dikehendaki, karena pada suhu yang tinggi asam lemak bebas dapat bereaksi dengan logam seperti besi, seng, timbal, mangan, kobalt, timah dan logam lainnya, dimana kejadian tersebut dapat mempercepat kerusakan komponen mesin diesel.

\section{Bilangan Penyabunan}

Angka penyabunan merupakan jumlah miligram $\mathrm{KOH}$ yang diperlukan untuk menyabunkan satu gram biodiesel. Dalam hal ini akan terjadi reaksi antara $\mathrm{KOH}$ dengan metil ester. Parameter ini adalah ukuran dari massa molekul relative rata-rata (panjang rantai) dari semua asam lemak yang terdapat dalam biodiesel. Angka penyabunan yang diperoleh pada penelitian ini 168.02. Dari hasil perhitungan, angka sabun biodiesel dari masing-masing sampel telah sesuai dengan syarat mutu biodiesel menurut SNI-04-71822006 sebesar $<500$.

\section{Bilangan iod}

Hasil analisis pada Tabel 4 memperlihatkan bahwa bilangan iod hasil penelitian sebesar 15.71. Bilangan iod yang tinggi merupakan sifat yang tidak menguntungkan untuk bahan bakar. Minyak yang mengandung asam lemak tak jenuh (memiliki ikatan rangkap) dalam jumlah yang tinggi akan mudah mengalami oksidasi ketika minyak tersebut mengalami kontak dengan oksigen. Karbon yang berikatan rangkap $(\pi)$ dengan karbon yang lainnya akan berikatan dengan oksigen akibat nilai kelektrogenatifan oksigen yang lebih tinggi. Hal ini dikarenakan oleh sifat ikatan pi yang agak kuran stabil sehingga mudah diserang oleh atom atau molekul luar.

Ketaren (2005) menjelaskan oksidasi biasanya dimulai dengan pembentukan peroksida dan hidroperoksida. Tingkat selanjutnya ialah terurainya asam-asam lemak disertai dengan konversi hidroperoksida menjadi aldehid dan keton serta asam-asam lemak bebas. Asam-asam lemak bebas inilah yang akan menyebabkan korosi pada mesin pembakar saat sampel minyak ini digunakan sebagai bahan bakar.

Adapun secara keseluruhan bilangan iod yang terkandung dalam biodiesel hasil penelitian tersebut masih memenuhi standar SNI 04-7182-2006, yakni tidak melebihi nilai 115. Semakin tinggi nilai bilangan iod, akan semakin tinggi pula jumlah asam lemak berikatan rangkap yang terkandung dalam minyak tersebut. Semakin banyak ikatan ganda yang dimiliki dalam sampel memiliki potensi 
yang lebih besar mengalami proses polimerisasi karena stabilitas yang lebih rendah.

\section{Analisa Komposisi Senyawa Penyusun Biodiesel dengan GCMS}

Metil ester yang diperoleh dari reaksi transesterifikasi selanjutnya dianalisis dengan menggunakan GCMS. Analisis ini menghasilkan puncak-puncak kromatogram yang masing masing menunjukkan jenis metil ester yang spesifik. Hasil analisa GCMS biodiesel hasil adsorpsi ditunjukkan pada Gambar 8.
Berdasarkan kromatogram dan tabel di atas, komponen utama yang terdapat di dalam sampel biodiesel adalah metil 9-oktadekanoat (49.45\%), metil heksadekanoat (20.79\%), dan metil 9,12-oktaekanoat (18.87\%). Dari data tersebut dapat dinyatakan memang benar senyawa biodiesel, yaitu metil ester. Analisa dengan GCMS menunjukan bahwa tidak terdapat senyawa asam lemak bebas yang terkandung dalam biodiesel. Ini menunjukan bahwa proses adsorpsi mampu menghasilkan biodiesel dalam bentu metil esternya.

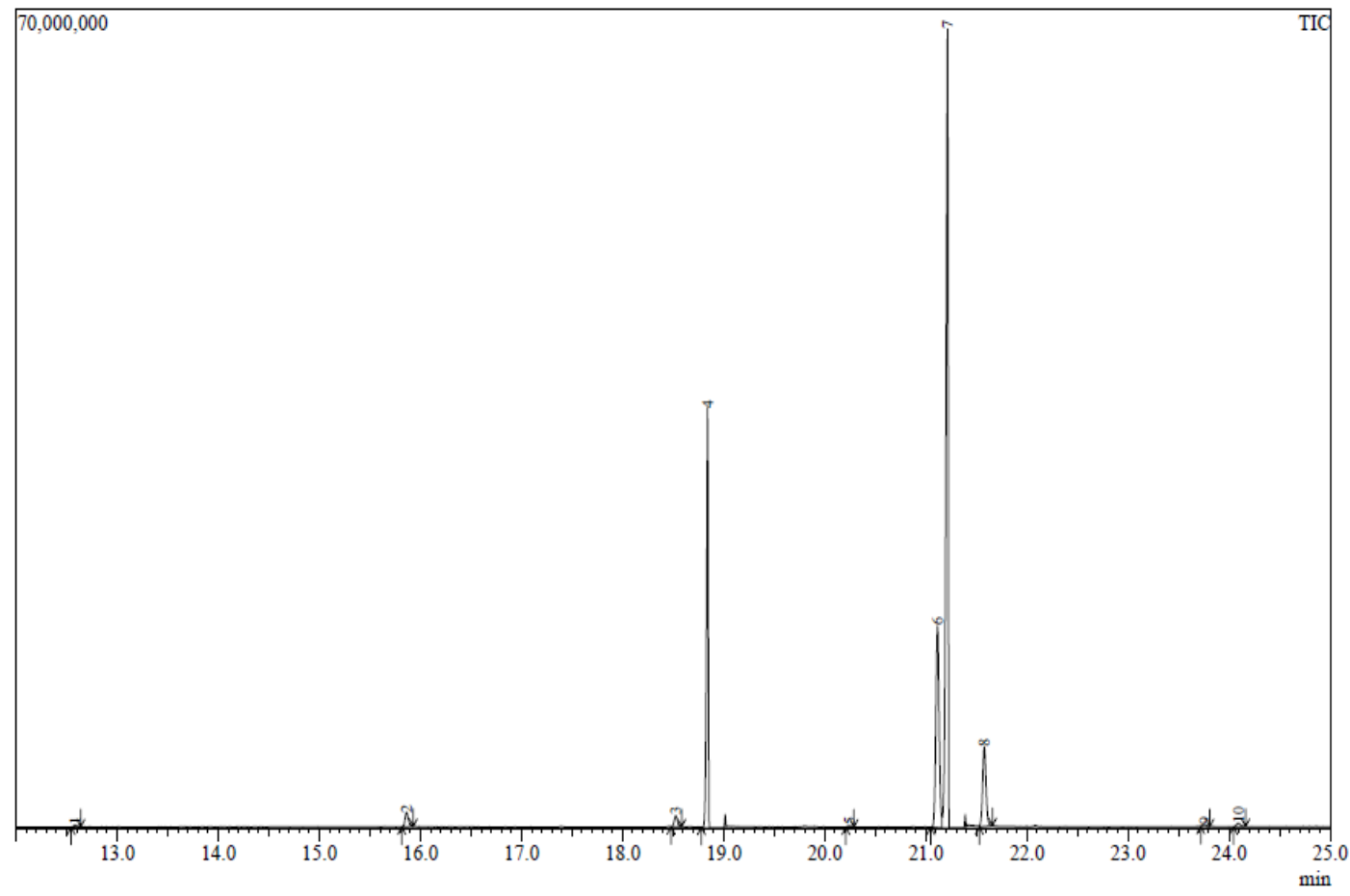

Gambar 8. Kromatogram biodiesel

Tabel 2. Senyawa yang terkandung dalam biodiesel

\begin{tabular}{cccccc}
\hline Puncak & $\begin{array}{c}\text { Luas } \\
\text { area(\%) }\end{array}$ & $\begin{array}{c}\text { Waktu } \\
\text { retensi }\end{array}$ & Nama senyawa & Rumus molekul & $\begin{array}{c}\text { Indeks } \\
\text { Similaritas }\end{array}$ \\
\hline $\mathbf{1}$ & 0.19 & 12.582 & Metil dodekanoat & $\mathrm{C}_{13} \mathrm{H}_{26} \mathrm{O}_{2}$ & 88 \\
$\mathbf{2}$ & 1.36 & 15.864 & Metil tetradekanoat & $\mathrm{C}_{15} \mathrm{H}_{30} \mathrm{O}_{2}$ & 92 \\
$\mathbf{3}$ & 0.96 & 18.527 & Metil 9-heksadekanoat & $\mathrm{C}_{17} \mathrm{H}_{32} \mathrm{O}_{2}$ & 88 \\
$\mathbf{4}$ & 20.79 & 18.841 & Metil heksadekanoat & $\mathrm{C}_{17} \mathrm{H}_{34} \mathrm{O}_{2}$ & 93 \\
$\mathbf{5}$ & 0.11 & 20.241 & 14- Metil heksadekanoat & $\mathrm{C}_{18} \mathrm{H}_{36} \mathrm{O}_{2}$ & 78 \\
$\mathbf{6}$ & 18.87 & 21.116 & Metil 9,12 oktadekanoat & $\mathrm{C}_{19} \mathrm{H}_{34} \mathrm{O}_{2}$ & 93 \\
$\mathbf{7}$ & 49.45 & 21.214 & Metill 9-oktadekanoat & $\mathrm{C}_{19} \mathrm{H}_{36} \mathrm{O}_{2}$ & 92 \\
$\mathbf{8}$ & 7.68 & 21.579 & Metil oktadekanoat & $\mathrm{C}_{19} \mathrm{H}_{38} \mathrm{O}_{2}$ & 95 \\
$\mathbf{9}$ & 0.19 & 23.758 & Metil 11- eikosenoat & $\mathrm{C}_{21} \mathrm{H}_{40} \mathrm{O}_{2}$ & 81 \\
$\mathbf{1 0}$ & 0.41 & 24.095 & Metil eikosenoat & $\mathrm{C}_{21} \mathrm{H}_{42} \mathrm{O}_{2}$ & 89 \\
\hline
\end{tabular}




\section{SIMPULAN}

Kondisi optimum dalam proses adsorpsi minyak goreng bekas sebagai bahan baku pembuatan biodiesel yaitu waktu reaksi 90 menit, konsentrasi zeolit $12 \%$, suhu $90{ }^{\circ} \mathrm{C}$, dan ukuran partikel $0.2 \mathrm{~mm}$ dengan kadar FFA $1.1 \%$. Kualitas biodiesel yang dihasilkan dalam penelitian ini yang meliputi kadar air, massa jenis, bilangan asam, bilangan iod dan bilangan penyabunan, memenuhi persyaratan SNI 04-7182-2006. Hasil analisa GCMS menunjukkan bahawa ada senyawa metil ester utama yang terkandung dalam biodiesel adalah metil 9-oktadekanoat (49.45\%), metil heksadekanoat (20.79\%), dan metil 9,12oktadekanoat (18.87\%).

\section{SARAN}

Pada penelitian ini masih diperlukan langkah-langkah lanjutan, yaitu perlu adanya variasi adsorben dalam menurunkan kadar FFA yang terkandung dalam minyak goreng bekas sebagai bahan baku pembuatan biodiesel Biodiesel yang dihasilkan juga perlu diuji menggunakan mesin lebih lanjut untuk mengetahui apakan biodiesel dapat digunakan sebagai bahan bakar.

\section{DAFTAR PUSTAKA}

Aziz I. 2007. Pembuatan biodiesel dari minyak goreng bekas dalam reaktor tangki berpengaduk. Valensi. 1(1): 19-23.

Aziz I, Nurbaiti S, Ulum B. 2011. pembuatan produk biodiesel dari minyak goreng bekas dengan cara esterifikasi dan transesterifikasi. Valensi. 2(2). 384-388.

Gerpen Vj. 2005. Biodiesel Processing And Production. Fuel Process Technol 86.1097-1107

Ketaren S. 1986 Pengantar Teknologi Minyak dan Lemak Pangan. Cetakan pertama. Jakarta. UI press.

Setiadji AHB. 1996. Zeolite material unggulan masa depan. Makalah Dalam Lokakarya Nasional Kimia, Yogyakarta.
Las T. 1989. Use of Natural Zeolite for Nuclear Waste Treatment, Departement Chemistry and Applied Chemistry, Salford University, UK (Mechlenbacher, V.C. 1960, The Analysis of Fats and Oils, Garrard Press Publishers, Champaign, IL.

Yusnimar. 2006. Pemanfaatan bentonit sebagai adsorbent pada proses bleaching minyak sawit. Prosiding Nasional Teknik Kimia Teknologi Oleo dan Ptetrokimia Industri ISSN : 1907-0500.

Suarya P. 2008. Adsorpsi pengotor minyak daun cengkeh oleh lempung teraktivasi asam. Jurusan Kimia FMIPA Univeritas Udayana, Bukit Jimbaran.

Suseno. 2010. Optimasi proses adsorpsi minyak goreng bekas dengan adsorben zeolit alam. Jurnal Kimia dan Teknologi. 6(1): 20-26.

Hidayat Y, Wibowo, Atmanto $\mathrm{H}$, Sulistyowati. 2010. Studi adsorpsi larutan gliserol menggunakan ZAA sebagai model pemisahan gliserol pada limbah produksi biodiesel. Jurnal Ekosains. II(3).

Susantiani E. 2009. Pengaruh temperatur larutan terhadap adsorpsi ion $\mathrm{Cd}+2$ dengan Co-Ion $\mathrm{Cu} 2+$ dalam berbagai konsentrasi oleh arang sekam padi dengan metode batch. Skripsi, FMIPA Universitas Negeri Malang.

Ramdja AF, Febrina L, Daniel K. 2010. Pemurnian minyak jelantah menggunakan ampas tebu sebagai adsorben. Jurnal Teknik Kimia. $1(17)$.

Pakpahan JF, Thomas T, Agnes H, Yusuf R. 2013. Pengurangan FFA dan warna dari minyak jelantah dengan adsorben serabut kelapa dan jerami. Jurnal Teknik Kimia USU. 2(1).

Sangha MK, PK Gupta, VK Thapar, Verma. 2005. Storage Studies on Plants Oil and Their Methyls Esters. College of Agricultural Engineering, Punyab Agricultural University, India. 